\title{
Analysis of Organizational Dimensions and the Role of Neighborhood Association/Rukun Tetangga Communications as a Partner of Village Governments in the Covid 19 Pandemic Period
}

\author{
Tatang Sudrajat*, Witri Cahyati, Leni Rohida \\ Universitas Sangga Buana \\ Bandung, Indonesia \\ *id.tatangsudrajat@gmail.com
}

\author{
Umi Rahmawati \\ Universitas Baturaja \\ Ogan Komering Ulu, Indonesia \\ umir1964@gmail.com
}

\author{
Fitra Nurhakim \\ STIA Bagasasi \\ Bandung, Indonesia \\ fitranurhakim.stiabagasasi@gmail.com
}

\begin{abstract}
There are many government problems in development and services to the community, especially during the Covid 19 pandemic. Support, participation and partnerships with various elements of society are a necessity. Rukun Tetangga as a lower-level social institution has a strategic role in development and public services. Setting the organizational dimension in a government regulation guarantees its implementation and function. The role of communication as a mediator between the interests of community members and the village government is very important. With qualitative methods, juridical normative, literature review and secondary data analysis, research located in Bandung and Cianjur regencies, it is known that as a social institution, the existence of the Rukun Tetangga is determined in several government regulations, namely Permendagri and regional regulations and regent regulations. Several organizational dimensions, namely formalization, specialization, organization and professionalization have been regulated in Law Number 6 of 2014, Government Regulation Number 43 of 2014, Permendagri 18 of 2018, Regional Regulation of Bandung Regency Number 12 of 2007, Perda of Cianjur Regency Number 4 of 2015, Regulations the Regent of Bandung Number 67 of 2011 and the Regulation of the Regent of Cianjur Number 16 of 2018. During the Covid 19 pandemic, the role of communication carried out by the Neighbourhood Association as a mediator between the interests of the community and the village government was very large. Some of these challenges and problems are reported by the Rukun Tetangga committee as a government partner in implementing communication and services to the community.
\end{abstract}

Keywords—organization, communication, neighborhood

\section{INTRODUCTION}

One of the functions of government is to serve the public interest in various fields of life. Local government in which there is a village government plays an important role in providing services to the community. In this regard, the village government is the spearhead as a front liner that directly deals with the community. The regulation regarding villages according to Article 4 letter $\mathrm{f}$ of Law Number 6 of 2016 concerning Villages [1] aims to improve public services for villagers in order to accelerate the realization of public welfare.

It has been more than eight months that the government and the people of Indonesia are facing the Covid 19 pandemic. In this context, the village government has experienced first-hand the dynamics of the implementation of services to the community amidst the economic pressure due to the impact of Covid 19. Therefore, the existence of the Rukun Tetangga (RT) as a social institution is very strategic in terms of efforts to improve the quality of government services provided to residents in the area. RT which according to Article 6 paragraph (1) Regulation of the Minister of Home Affairs (Permendagri) Number 18 of 2018 [2] is one of the types of village social institutions, one of its duties according to Article 4 paragraph (1) letter $\mathrm{c}$ is to improve village community services. One of its functions according to Article 5 letter $\mathrm{c}$ is to improve quality and accelerate village government services to village communities.

Stakeholders in handling the Covid 19 pandemic, especially RT administrators and their staff certainly understand very well the dynamics of the problems that arise as a public response to social assistance provided by the government with all its 
consequences. Based on tracing data from several RTs in Cianjur and Bandung Regencies, it appears that various obstacles, challenges, and problems always confront at every stage of providing social assistance to community members. One of the problems that has arisen that is part of the dynamics of service delivery is that data on aid recipients is almost always out of synchronization between the RT and those from the government. This is certainly one of the defects in the delivery of public services at a macro level that can reduce the meaning and reputation of the government as a public servant at the local level.

In this context, the existence of the RT as an organization will be a determining factor in the formation of a positive image of the government as a public servant. The implementation of its duties as a partner of the local government in providing services to the community will also be determined by the regulation of various organizational aspects in the government regulations that form it. In this connection, the organizational dimension inherent in the institution will determine its characteristics as an organization.

According to Lubis, in an analysis of an organization, it is often necessary to first find the characteristics of the organization. Determining the characteristics can only be done if the dimensions of the organization are known in advance. Based on these dimensions, the characteristics of an organization can be formulated [3]. According to him 'the organizational dimension consists of a structural dimension and a contextual dimension. The structural dimension consists of formalization, specialization, standardization, centralization, hierarchy of power (authority), complexity, professionalism, and configuration. The contextual dimension consists of size, technology and organizational environment '[3].

In addition, the effectiveness of this service function will also be determined by the quality of communication played by the RT management, especially the Chairman. The process of effective communication between RT and community members in providing services, especially in the form of distribution of social assistance packages, will certainly foster a positive public image and perception of the government. In turn, this will become the main pillar of credible and accountable governance in the public view.

This study aims to discuss the arrangement of the organizational dimensions of the RT as an organization in several government regulations and the role of communication as a government partner in providing services to the community during the Covid 19 pandemic.

\section{RESEARCH METHODS}

This research uses a combination of qualitative methods, normative juridical, library research and secondary data analysis. The focus of the researcher's attention is directed at various laws and regulations at various levels of government regarding the duties and functions of the RT as well as various literatures in the form of books, journals, documents, and other scientific writings on the theme of RT organizations and their communication role as partners of the village government. In addition, in-depth interviews were conducted with several RT heads in Bandung Regency and Cianjur Regency.

The regulations that are the focus of the research are Law Number 6 of 2014, Government Regulation Number 43 of 2014, Permendagri Number 18 of 2018, Regional Regulation of Cianjur Regency Number 4 of 2015, Regional Regulation of Bandung Regency Number 12 of 2007, Regulation of the Regent of Cianjur Number 16 of 2018 and Bandung Regent Regulation Number 67 of 2011.

Data analysis in the form of government regulations was carried out by content analysis, while the interview data was carried out using qualitative techniques from the start along with the research findings in accordance with the focus of the discussion. Referring to Miles and Huberman, the data were analysed with three activity streams that occurred simultaneously as a cyclical and interactive process, namely data reduction, data presentation and conclusion / verification [4].

\section{RESULTS AND DISCUSSION}

\section{A. Organizational Characteristics}

RT as one of the types of village social institutions is explicitly listed in the Explanation of Number I. General item 11 of Law Number 6 of 2014, Elucidation of Article 150 paragraph (1) of Government Regulation Number 43 of 2014, Article 6 paragraph (1) of Permendagri Number 18 of 2018, Article 13 letter d Bandung Regency Regional Regulation/Perda Number 12 of 2007, Article 86 letter d Cianjur Regency Regional Regulation/Perda Number 4 of 2015, Article 1 number 17 Bandung Regional Regulation/Perbup Number 67 of 2011, and Article 1 number 17 and Article 7 letter c Cianjur Regional Regulation/Perbup Number 16 Year 2018.

As one type of village community organization, RT is an organization, because it consists of a group of people who are bound by a certain norm to work together to achieve the goal of its formation. The organization is mentioned by Pfiffner and Presthus as 'the structuring of individuals and functions into productive relationships. Organization seeks a pattern of skills and responsibilities that will ensure coordination and unity of purpose through supervision'[5]. Organization according to Dwight Waldo is 'the structure of authoritative and habitual personal interrelations in an administrative system' [6].

The purpose of forming the RT is basically identical to the goal of its regulation by the government as stated in Article 2 letter c Permendagri Number 18 of 2018, which is to ensure the smooth running of village government services. Likewise, according to Article 1 point 2 of the Permendagri, what is meant by Village Community Institutions is a forum for community participation, participating in planning, implementation, and supervision of development, as well as improving village community services. 
With the basis of its formation in various government regulations and its duties attached to the existence of the government, it is not surprising that some members of the community think that RT is a government institution. Especially when it comes to dealing with broad public interests, such as currently being faced with socio-economic problems due to Covid 19. According to Utomo, structurally the RT is not part of the regional government so that there is no span of command and control between the village and the RT, but functionally. can be categorized as part of the local government apparatus that helps part of government tasks. RT is one of the main components in the concept of communitycantered local government [7].

Referring to Talcot Parsons about the type of organization, this RT as an organization can be categorized as political organization, because 'political organization are concerned with ensuring that society as a whole achieves its objectives' [8]. This is in line with the normative regulation of RT which, although not a government institution, is fully regulated by government regulations whose duties are directly related to the public interest. Likewise, the role of assistance and partnerships in providing services to community members further strengthens its position as an organization. This is in line with what James G. March and Herbert A. Simon stated that one of the characteristics of an organization is provide services and product to their environment [9].

The working relationship in the organization will show the characteristics of the organization concerned. In this connection, the working relationship between the RT and the village government is regulated in:

- Permendagri Number 18 of 2018 in Article 12 paragraph (1) states that the working relationship between village community organizations and village government is a partnership [2].

- Bandung Regency Regional Regulation/Perda Number 12 of 2007 in Article 29 paragraph (1) states that the working relationship of social institutions with village government is partnership, consultative and coordinative [10].

- Perbup Cianjur Number 16 of 2018 in Article 21 paragraph (1) that the relationship is partnership, consultative and coordinative [11].

- Perbup Bandung Number 67 of 2011 in Article 20 paragraph (3) that the relationship is based on the principles of consultative, coordinative and intensive coaching in the implementation of service tasks to the community [12].

This affirmation of the organizational relationship with the village government, especially as a partner, is very important given the RT's position which is not a subordinate of a government institution.

Based on the provisions of several state / government regulations, it is clear that the RT has a position as a social institution as a partner of the village government in providing services to the community. During the Covid 19 pandemic, the actualization of its duties and functions was felt by the community in providing social assistance services allocated by the government. The position of the RT as a meaningful partner that is not subordinate to the village / kelurahan government organizationally is the right thing because the community members who are willing to become heads and administrators of the RT are generally more likely to volunteer for reasons. Likewise, the term "service" which is mentioned in all government regulations is an important affirmation of public service as one of the essential functions of government.

\section{B. Organizational Dimension Arrangement}

The organizational dimension according to Daft consists of a structural dimension and a contextual dimension. Structural dimensions according to him 'provide labels to describe the internal characteristics of an organization. They create a basis for measuring and comparing organizations. It is further stated that the structural dimensions consist of 'formalization, specialization, standardization, hierarchy of authority, complexity, centralization, professionalism, dan personnel ratios. Furthermore, it was stated that 'contextual dimensions characterize the whole organization. Including its size, technology, environment, and goals. They describe the organizational setting that influences the structural dimensions. The contextual dimension consists of 'size, organizational technology, the environment, the organization's goals and strategy and an organization's culture'[13]. Based on Daft's opinion it is clear that the existence of these structural and contextual dimensions is very important for analysing the complete posture of an organization.

The sub-dimensions of "formalization" and "specialization" are listed in:

- Law Number 2014 in Article 94 paragraph (3) states that village community organizations are tasked with empowering village communities, participating in planning and implementing development, and improving village community services [1].

- Government Regulation/PP Number 43 of 2015 in Article 150 paragraph (2) letter c states that village social institutions are tasked with improving village community services. Its function is stated in Article 150 paragraph (3) letter c, namely, to improve quality and accelerate village government services to village communities [14].

- Permendagri Number 18 of 2018 in Article 4 paragraph (1) letter $\mathrm{c}$ states that village social institutions are tasked with improving village community services. In addition, Article 5 letter $\mathrm{c}$ states that the function of village community institutions is to improve the quality and accelerate village government services to village communities [2]. 
- Cianjur Regency Regional Regulation/Perda Number 4 of 2015 in Article 84 paragraph (4) number 1 concerning the duties of village social institutions, namely improving village community services. In addition to that in paragraph (5) letter $\mathrm{c}$ about its function, namely improving quality and accelerating village government services to village communities [15].

- Bandung Regency Regional Regulation/Perda Number 12 of 2007 in Article 7 paragraph (1) states that village community institutions have the task of assisting the Village Government and are partners in empowering village communities. One of its functions as referred to in Article 9 paragraph (1) letter $\mathrm{c}$ is to improve the quality and acceleration of government services to the community. In particular, Article 22 states that the RT has the task of assisting the Village Government and Lurah in the administration of government affairs. One of its functions as referred to in Article 23 letter a is population data collection and other government administration services [10].

- Perbup Cianjur Number 16 of 2018 in Article 3 paragraph (1) letter $\mathrm{c}$ that the task of social institutions is to improve village community services. In addition, Article 12 states that the RT's duty is to assist the Village / Kelurahan Government in the framework of providing services and administering government affairs. Its function is mentioned in Article 13 letter a, namely population data collection and other government administration services [11].

- Perbup Bandung Number 67 of 2011 in Article 3 letter a that one of the RT's duties is to help carry out service tasks to the community which are the responsibility of the local government [12].

The subdimension of "organizational goals" is contained in:

- Permendagri Number 18 of 2018 in Article 2 letter c states that the purpose of regulating village social institutions is to ensure the smooth running of village government administration services [2].

- Bandung Regency Regional Regulation Number 12 of 2007 in Article 6 letter b is to improve government services, management, planning, implementation of development and community empowerment in villages and sub-districts [10].

- Perbup Bandung Number 67 of 2011 in Article 2 paragraph (2) letter $b$ that the purpose and objective of establishing RT is to improve services and community empowerment in community development [12].

The purpose of forming an organization or organizational goals is very important as a guide for the operationalization of its duties and functions. Cianjur Regency Regional Regulation Number 4 of 2015 [15] and Cianjur Regent Regulation Number 16 of 2018 do not regulate this [11].
The sub-dimension of "professionalization" is stated in the Bandung Regulation No. 67/2011 in Article 11 point 8 [12] that the requirements for the Head of the RT are to be educated at the lowest SLTP or equivalent or have social knowledge. In the Perbup Cianjur Number 16 of 2018 [11] there is no stipulation regarding the minimum education requirements for the RT management. The educational background, competence and educational qualifications of the organization's management will greatly determine the overall performance of the organization. In the informational and digital era marked by the increasingly critical and responsive community members to the current government service functions, the level of education of at least SMA or equivalent needs to be regulated as one of the requirements for a person to become Chairman or RT administrator in government regulations.

The subdimension of "organizational size" is contained in:

- Permendagri Number 18 of 2018 in Article 8 paragraph (1) concerning the number and designations of the social institution administrators [2]

- Bandung Regency Regional Regulation Number 12 of 2007 in Article 28 paragraph (1) concerning the number and designations of social institution management positions [10].

- Perbub Cianjur Number 16 of 2018 in Article 20 paragraph (1) concerning the number and designations of social institution administrators [11].

- Perbup Bandung Number 67 Year 2011 in Article 10 paragraph (1) concerning the number and designations of RT administrators [12].

Regulating the number and title of RT management positions as social institutions is very important for the effectiveness of an organization in achieving its objectives. Cianjur Regency Regional Regulation Number 4 of 2015 [15] does not specifically regulate this matter.

\section{COMMUNICATION AND DUTIES OF NEIGHBORHOODS ASSOCIATION}

RT according to Article 6 paragraph (1) Regulation of the Minister of Home Affairs Number 18 of 2018 concerning Village Community Institutions and Village Traditional Institutions [2] is one type of Village Community Institution. One of the duties of the Village Community Institution according to Article 4 paragraph (1) is to improve village community services. The functions according to Article 5 include accommodating and channelling community aspirations as well as improving the quality and accelerating village government services to village communities. Simangunsong stated that the RT institution has a very important role in providing services to the community [16].

The working relationship between the Village Community Institution and the Village Government as stated in Article 12 paragraph (1) is a partnership. RT according to the provisions of Article 7 has several tasks, including assisting the Village 
Head in the field of government services; and carry out other tasks assigned by the Village Head. As in the village, Zuhdi et al concluded that RT as a village partner plays a very important role in governance and development, as a bridge that connects the interests of the community with the government [17]. Thus, RT administrators are government partners at the lowest level to make the national development program successful, including the provision of social assistance. In this connection, the process of organizational communication between the RT and the village government as well as with community members is very important.

In Bandung Regency, Regional Regulation Number 12 of 2007 concerning Social Institutions [10] has been issued. Article 23 letter a state that one of the Rukun Tetangga's functions is population data collection and other government administration services. As a follow-up to the Regional Regulation, Regent Regulation Number 67 of 2011 concerning Rukun Tetangga (RT) and Rukun Warga (RW) [12] has been issued, which in Article 2 Paragraph (1) states that RT and RW are community organizations domiciled in villages and Kelurahan and become a partner of the Regional Government. Thus, it is clear that each RT that is a partner of the regional government at the lowest level is truly very large and decisive for the realization of government service functions to the people. This is partly because in general the RT administrators in each region are community leaders, opinion leaders, and community activists who are very effective in assisting each government program.

The communication process between the village government and the RT management / head is very important in providing services to community members. Communication according to Everett $M$. Rogers is a process where an idea is transferred from a source to a recipient or more with the intention of changing their behaviour [18]. Communication between residents can run according to purpose if there is a leader or RT head who has credibility and a leadership style to create citizen participation in decision making for development [19]. As a partner of the village government, the Head of RT in each region fought as both a communicator and a communicant. As a communicant, when the village government delivers information directly to the RW or RT head in several meetings at the village office. The role as a communicator is inherent in the head of the RT when he gets information about assistance from the government for residents affected by Covid 19. The message comes from the village government through the head of the RW which is delivered in the form of an official circular.

The media or means of communication used by the Head of the RT to further inform members of the community in several ways, namely by coming directly to the target community (door to door), especially those affected by Covid 19 and who do not have a mobile phone. Those who have cell phones are done by calling or via the RT WhatsApp group. In addition, by holding a meeting or meeting with residents at the house of a member of the community. Sometimes it also uses recitation forums at mosques, majlis taklim or Friday forums.
The information provided by the Head of the RT to community members about social assistance consists of the Family Hope Program/PKH, with an amount of Rp. 400,000 to Rp. 600,000 per month; BPNT per month in the form of basic necessities plus money; The temporary BST is sometimes IDR 600,000 per month; Assistance from the Ministry of Social Affairs Rp. 300,000; BLT village funds Rp. 300,000, - and assistance from the provincial and district government in the form of basic foodstuffs

Several challenges and problems were faced by the Head of the RT as a partner of the village government during the Covid 19 pandemic. In addition, as the spearhead of the service who directly faces community members, the RT head faces several dilemmas. Because once the information was conveyed, it turned out that there were not a few community members who were actually able socio-economically but wanted to be included in the list to be proposed as beneficiaries of assistance. There were also residents who had actually died when the assistance arrived, then their heirs came to ask for assistance because they felt they had the right. There are also some members of the community who have moved from domicile but come back to the RT management to ask for this assistance. Community members sometimes also do not submit the required documents as stipulated, including some who do not have a family card and an E KTP. The village government, through its apparatus, sometimes comes down directly to witness the process of distributing basic necessities or conducts cross-checks with community members.

The distribution of social assistance, including basic foodstuffs, is basically part of the implementation of public policy, because it is actually something that is passed on to the community as a government program. In this context, clarity of information is very important to be conveyed by RT administrators to the community. In the socio-economic conditions of the people who have been hit due to Covid 19, of course there is a big challenge for the Head of the RT to be very careful in providing explanations to them.

The decision-making process in crisis conditions, including in handling Covid 19, in terms of distribution of social assistance, of course, very much depends on many factors, one of which is the lack of information [20]. In this context, there were big challenges and tests for RT heads as community leaders at the grassroots level. Credibility as a leader and servant in society is often at stake because it is faced with two pressures. From the "above", namely from the village government there is a target so that all aid programs can reach the community smoothly according to the schedule and list of those entitled to receive. From the "bottom" side, there is also the pressure to accommodate various interests, especially those with economic motives.

As part of the communication process, the existence of feedback is very important in order to serve the community. The head of the RT often receives criticism / suggestions / input from community members about the difference between the data submitted by the residents and the fact that the list / 
data comes from the government. There are also community members who expect the value / amount of this assistance to be increased. This includes members of the community who feel they have the right to help but are in fact not on the list, so they perceive the RT head as favouritism or discriminating against residents.

\section{CONCLUSION}

RT as a social institution plays a strategic role in helping the government serve the community, especially during the Covid 19 pandemic. Organizational dimension settings in several government regulations have been seen, namely formalization, specialization, organizational objectives, organizational size, professionalization in Law, Government Regulation, Permendagri, District Regulations and Perbup. As a partner of the village government, RTs are faced with various challenges and problems when providing services to the community. Communication with the village government and community members generally runs smoothly. There are several suggestions from community members to the government to further improve the quality of services and the amount of assistance provided.

Regulating the dimensions of the RT organization in government regulations needs to be even more comprehensive in order to strengthen its institution as the spearhead of services to the community. The role of RT communication to community members, especially during the Covid 19 pandemic, needs to be improved.

\section{REFERENCES}

[1] UU Nomor Tahun 2014 tentang Desa.

[2] Peraturan Menteri Dalam Negeri Nomor 18 Tahun 2018 tentang Lembaga Kemasyarakatan Desa dan Lembaga Adat Desa.

[3] H. Lubis, Organisasi. Jakarta: Universitas Terbuka, 2008.

[4] B. Miles and A. Huberman, Analisis Data Kualitatif. Jakarta: UI Press, 1992
[5] J. Pfiffner and P. Robert, Public Administration. New York: Ronald Press, 1960

[6] D. Rosenbloom, Contemporary Public Administration. New York: McGraw-Hill. Inc., 1994.

[7] T.W.W.U.B.M. Andalina, "Pengembangan Kapasitas Rukun Tetangga/Rukun Warga Sebagai Organisasi 'Akar Rumput' Dalam Era Desentralisasi Luas” J. Ilmu Adm., vol. 6, no. 1, 2009.

[8] V. Narayanan and R. Nath, Organization Theory. A Strategic Approach. Homewood IL Boston: Richard D. Irwin Inc., 1993.

[9] N. Henry, Public Administration and Public Affairs. London: PrenticeHall International, Inc., 1989.

[10] Peraturan Daerah Kabupaten Bandung Nomor 12 Tahun 2007 tentang Lembaga Kemasyarakatan

[11] Peraturan Bupati Cianjur Nomor 16 Tahun 2018 tentang Pedoman Penataan Lembaga Kemasyarakatan.

[12] Peraturan Bupati Bandung Nomor 67 Tahun 2011 tentang Rukun Tetangga (RT) dan Rukun Warga (RW).

[13] R. Daft, Organization Theory and Design. Fourth Edition. Singapore: Info Access Distribution Pte Ltd, 1992.

[14] Peraturan Pemerintah Nomor 43 Tahun 2015 tentang Pelaksanaan UU Nomor 6 Tahun 2014 tentang Desa.

[15] Peraturan Daerah Kabupaten Cianjur Nomor 4 Tahun 2015 tentang Desa.

[16] F. Simangunsong, Analisis Peranan Rukun Tetangga Dalam Membantu Tugas Pemerintahdi Kota Bandung, vol. 5. Visioner: Jurnal Pemerintahan Daerah di Indonesia, 2011.

[17] S. Zuhdi, A. Ferizko, and P. Melinda, "Penguatan Kelembagaan Rukun Tetangga Dan Rukun Warga (Rt/Rw) Di Kelurahan Rintis Kecamatan Lima Puluh Kota Pekan Baru,” J. Manaj. Pelayanan Publik, vol. 3, no. 1, Art. no. 1, 2019, doi: 10.24198/jmpp.v3i1.23683.

[18] Nurudin, Ilmu Komunikasi. Ilmiah dan Populer. Jakarta: PT Raja Grafindo Persada, 2017

[19] N. Vellayati, S. Sarwoprasodjo, and C. T. Wibowo, "Efektivitas Komunikasi Kepemimpinan Transformasional Ketua RT Terhadap Partisipasi Warga Di Kabupaten Bogor (Communication Effectiveness Transformational Leadership Head of the Neighbourhood Community Against Citizens Participation in Kabupaten Bogor)," J. Komun. Pembang., vol. 14, no. 2, Art. no. 2, Oct. 2016, doi: $10.46937 / 14201613765$

[20] Z. S. Al-Dabbagh, "The Role of Decision-maker in Crisis Management: A qualitative Study Using Grounded Theory (COVID-19 Pandemic Crisis as A Model),” J. Public Aff., vol. 20, no. 4, p. e2186, 2020, doi: https://doi.org/10.1002/pa.2186. 